\title{
Effects of an atypical drought on the benthic macroinvertebrate community in a tropical reservoir
}

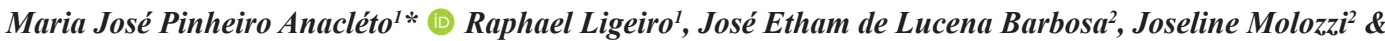 \\ Marcos Callisto ${ }^{3}$ \\ ${ }^{1}$ Universidade Federal do Pará, Instituto de Ciências Biológicas, Laboratório de Ecologia e Conservação, Belém, PA, Brasil \\ ${ }^{2}$ Universidade Estadual da Paraíba, Departamento de Ciências Biológicas, Programa de Pós-Graduação em \\ Ecologia e Conservação, Campina Grande, PB, Brasil \\ ${ }^{3}$ Universidade Federal de Minas Gerais, Instituto de Ciências Biológicas, Departamento de Biologia Geral, \\ Laboratório de Ecologia de Bentos, Belo Horizonte, MG, Brasil \\ *Corresponding author: Maria José Pinheiro Anacléto, e-mail: mariajose_anacleto@yahoo.com.br
}

ANACLÉTO, M. J. P., LIGEIRO, R., BARBOSA, J. E. de L., MOLOZZI, J., CALLISTO, M. Effects of an atypical drought on the benthic macroinvertebrate community in a tropical reservoir. Biota Neotropica. 18(2): e20170352. http://dx.doi.org/10.1590/1676-0611-BN-2017-0352

\begin{abstract}
Atypical drought events have increasingly occurred in Brazil over the last years due to global climate changes. However, their consequences on aquatic biota in reservoirs are poorly known. We tested the hypothesis that macroinvertebrate communities are negatively affected by atypical drought events, given the sensitivity of many taxa to environmental changes. We predicted that: (a) there would be changes in limnological and sediment parameters between a regular year and an atypical year, (b) abundance and richness of the genera of Chironomidae and of exotic species would be higher due to the enhanced ability of these organisms to adapt to changes in the physical environment, and (c) community structure metrics (i. richness; ii. \% richness; iii. abundance; iv. \% abundance) would be affected by disturbance indices (i. Buffer Disturbance Index-BDI; ii. Local Disturbance Index-LDI; iii. Integrated Disturbance Index-IDI) in both years. The study was carried out in the reservoir of the Nova Ponte Hydroelectric Power Plant, state of Minas Gerais, comparing two sampling periods: a regular climatological year (2010) and an atypical drought year (2014). A total of 40 sampling sites were defined along the shore of the reservoir, and types of land use in the surrounding area of each site were measured, as well as physical habitat conditions, sediments, and benthic macroinvertebrate communities. Sampling was performed at these sites in the end of the rainy season in both years. The intensity of anthropogenic modifications was assessed at local scale and in the areas (buffers) surrounding the sampling sites using quantitative disturbance indices. There were striking differences in limnological parameters and sediment characteristics between sampling periods. Taxonomic richness was significantly lower in the drought year. As opposed to our predictions, richness and abundance of Chironomidae and exotic species did not increase with the atypical drought event. Besides, most community structure metrics showed a significant relationship with disturbance indices only during the regular climatological year, thus indicating that the large-scale effects of water stress may override the conditions of local habitats and the surrounding landscape. Therefore, in addition to a correct political-environmental management of water resources at local-scale, which includes maintaining the water quality and the riparian and landscape integrity, addressing large-scale climate issues is required for the maintenance of the ecological integrity of tropical reservoirs.
\end{abstract}

Keywords: Benthic fauna, exotic species, ecological integrity, water stress, climate changes.

\section{Efeitos de uma seca atípica sobre a comunidade de macroinvertebrados bentônicos em um reservatório tropical}

Resumo: A ocorrência de episódios atípicos de seca vem crescendo nos últimos anos no Brasil em decorrência de mudanças globais no clima. Entretanto, as consequências disso para a biota aquática são ainda pouco conhecidas. Testamos a hipótese de que comunidades de macroinvertebrados são negativamente afetadas por eventos de seca atípica, dada a sensibilidade de muitos taxa às alterações ambientais. Nossas predições foram que (a) parâmetros limnológicos e características de sedimento seriam alterados em um ano de seca atípica, (b) encontraríamos maior abundância e riqueza de gêneros de Chironomidae e de espécies exóticas dada à alta capacidade destes organismos de adaptarem-se às mudanças no ambiente, (c) métricas de estrutura de comunidade (i. riqueza; ii. \% riqueza; iii. abundância e iv. \% abundância) seriam afetadas por índices de distúrbio (i. Índice de Distúrbio no Buffer-IDB; ii. Índice de Distúrbio Local-IDL e iii. Índice de Distúrbio Integrado-IDI) em ambos os anos. O estudo foi realizado no reservatório 
da Usina Hidrelétrica de Nova Ponte, Minas Gerais, comparando dois períodos amostrais: um ano climatológico normal (2010) e um ano de seca atípica (2014). Foram definidos 40 sítios amostrais na região litorânea do reservatório onde foram mensurados os tipos de usos do solo no entorno, condições de habitats físicos, características limnológicas na coluna d'água, sedimento e comunidades de macroinvertebrados bentônicos. A intensidade de alterações antrópicas foi avaliada em escala local e no entorno dos pontos amostrais (buffers) por meio de índices de distúrbio. Observamos diferenças expressivas nos parâmetros limnológicos e nas características dos sedimentos entre os dois períodos amostrais. A riqueza taxonômica foi significativamente menor no ano de seca. Ao contrário do esperado, os valores de riqueza e abundância de Chironomidae e de espécies exóticas não aumentaram com o evento extremo de seca. Paralelamente, a maioria das métricas de estrutura de comunidade apresentou relação significativa com os índices de distúrbio somente durante o ano climatológico normal, indicando que os efeitos de estresse hídrico em larga escala podem se sobrepor às condições locais de habitat e de paisagem circundante. Portanto, deve ser considerada não só a correta gestão político-ambiental de recursos hídricos em escala local, que inclui a manutenção da qualidade da água e da integridade da região ripária e uso do solo da região de entorno, mas também abordar questões climáticas em larga escala faz-se necessário para a manutenção da integridade ecológica em reservatórios tropicais.

Palavras-chave: Fauna bentônica, espécies exóticas, integridade ecológica, estresse hídrico, mudanças climáticas.

\section{Introduction}

Scarcity of water resources is one of the most debated environmental issues worldwide, as it is one of the greatest challenges of this century (Dobrovolski \& Rattis 2015), and changes in rainfall regimes are responsible for exacerbating the occurrence of droughts across the globe (Ledger et al. 2012). Extreme climatic events have been increasing over the last fifty years in southeastern Brazil (Marengo 2009). From 2012 to 2014, the drought resulted in 56 trillion liters of water deficit per year due to a precipitation approximately $16 \%$ lower than the yearly historical average (Getirana 2015). That is why the extended drought in 2014 caused huge economic losses in hydropower energy generation (Getirana 2015). In general, rains have been lower than the Climatological Normal, and 2013 and 2014 were classified as very dry years according to the report on the assessment of precipitation in river basins of the Minas Gerais State Water Management Institute (IGAM 2014). The water level in Nova Ponte Hydroelectric Power Plant reservoir (Nova Ponte HPP), in the State of Minas Gerais, was $84 \%$ of its total volume in April 2010, end of the rainy season. In April 2014, this volume reached $25 \%$, and in April 2015, it reached 22\% (ONS 2015). Climate change studies have shown increased occurrence of atypical drought events (Romm 2011, Gaeta et al. 2014), and their consequences on aquatic macroinvertebrates communities such as loss of native species, expansion of exotic species and changes in nutrient cycling (Carpenter et al. 2011).

Changes in water temperature, food web dynamics, species composition and ecosystem productivity have been observed in reservoirs with the increase of overall air temperature (Williamson et al. 2009). Therefore, it is possible that reservoirs can act as environmental sentinels of signs of climate changes, as being proposed for lakes (Taner et al. 2011). Studies show that decreased water level in these environments cause habitat degradation and have impact on aquatic organisms, including dryness of sediments and death of macrophytes at the littoral zone and the consequent simplification of assemblages (Hofmann et al. 2008, Sutela et al. 2013, Magbanua et al. 2015). Hydropower plant reservoirs are already very unstable environments, because water depletion is usually high and changes in water level are frequent (Tang et al. 2016). Hence, climate changes are expected to further magnify the unstable conditions in reservoirs due to increased occurrence of atypical droughts (Magbanua et al. 2015). One of the major impacts of decreased water level in reservoirs is the exposure and drying of sediments in the shore (Bond et al. 2008, Hofmann et al. 2008). This exposure leads to physical habitat homogenization and decreased complexity in shore sediments, consequently reducing the availability of food resources and refuge for aquatic biota (Hofmann et al. 2008, Kaufmann et al. 2014a, b).

Few ecological studies in tropical regions have assessed the environmental integrity of hydropower reservoirs over time (e.g., Mackay et al. 2010). However, sampling at distinct environmental conditions is necessary to detect trends of changes in freshwater assemblages (Resh et al. 2013), including those generated by large-scale climate changes (Lake 2000, Lake 2003). Analyses of the ecological conditions of these ecosystems have been conducted using water quality bioindicators (Martins et al. 2015), including benthic macroinvertebrate community (Morais et al. 2017) and exotic species (Azevêdo et al. 2016, Linares et al. 2017). The integrated analysis of biological metrics and information on land use, physical habitat conditions, and water quality enables ecological assessment at multiple spatial scales (Macedo et al. 2016, Ferreira et al. 2017, Castro et al. 2017). The identity of bioindicators in reservoirs is different from that of streams and rivers, e.g. insect orders Ephemeroptera, Plecoptera, and Trichoptera (EPT), which are considered good indicators in lotic ecosystems but are rarer in lakes and reservoirs (Borisov et al. 2016). On the other hand, Chironomidae are very abundant and diverse in lentic ecosystems. This family can dwell in a wide range of environmental conditions (Corbi \& Trivinho-Strixino 2016, Saulino et al. 2017), shows a good response to environmental degradation (Árva et al. 2015, Brandimarte et al. 2016), and is a potential biological indicator of climate changes (Ilyashuk \& Ilyashuk 2007). Recently, Morais et al. (2017) pointed out that water level depletion on hydropower reservoirs favours chironomids as early colonizers, as they rapidly colonize recently-flooded areas.

Another metrics which have been gaining importance in biomonitoring studies are the presence and abundance of exotic species (Linares et al. 2017). These species can cause deep changes in ecosystems and their communities if they become invasive, and are considered the second leading cause of biological diversity loss, after habitat loss (Strayer 2010, Silva \& Barros 2011). The introduction and constant dispersal of exotic species in aquatic ecosystems are facilitated by human activities (e.g., ballast water transport, use of species as fish bait, releases from recreational production, and juvenile fixation onto ship hulls) (Sousa et al. 2008). Reservoirs are especially vulnerable to the invasion of exotic species as they receive continuous input of biological materials derived from the main river and its tributaries (Rocha et al. 2011). These species might be subsequently transported downstream and colonize other sections of the river basins (Rocha et al. 2011). The increase in extended droughts might also change the environmental filters that determine how successful exotic species are in colonizing new habitats (Rahel \& Olden 2008, Gama et al. 2017, McDowell et al. 2017). However, in certain situations, water stress might reduce the negative effects of exotic species on the environment, minimizing the spatial overlap between native and exotic species (Taner et al. 2011).

Considering that extreme drought events tend to be more frequent over the next decades (IPCC 2016), the aim of this study was to assess how composition and structure of benthic macroinvertebrate communities change in atypical drought conditions in a hydroelectric power plant reservoir in the Brazilian cerrado. We worked with the hypothesis that an extreme drought event is detrimental to macroinvertebrate communities, with the exception of organisms resistant to environmental changes, including the 
Chironomidae family and the exotic species. Our first prediction is that macroinvertebrate diversity might decrease with decreased water volume, with a simultaneous increase in Chironomidae richness and abundance. Our second prediction is that the abundance of exotic species might increase in the drier year, as these species usually have high ecological plasticity and are tolerant to environmental changes. Finally, our third prediction is that disturbances acting at different spatial scales might affect the biological metrics, but this influence is not as strong in genera of Chironomidae and in exotic species.

\section{Material and Methods}

\section{Study Area}

Nova Ponte Reservoir is located in the middle section of the Araguari river basin in the Cerrado of Minas Gerais State, southeastern Brazil (Figure 1). It was built in 1987 and started to operate in 1994. According to Köppen's classification, the climate in the region is AWA (tropical with hot rainy summers and dry winters), with temperatures ranging between $14^{\circ} \mathrm{C}$ and $30^{\circ} \mathrm{C}$ and mean annual rainfall of approximately $1700 \mathrm{~mm} /$ year (Durães et al. 2001). Dry season typically spans from May to September, whereas rainy season spans from October to April. Nova Ponte Reservoir is the largest in a series of cascade reservoirs in the Araguari River, with a surface area of $443 \mathrm{~km}^{2}$ and maximum accumulation volume of 12.8 billion $\mathrm{m}^{3}$ of water (CEMIG 2015). Its hydroelectric power plant houses three power generating units with a total capacity of $510 \mathrm{Mw}$. Its dam wall has a maximum height of 142 meters and is 1600 meters long, and its residence time is $\sim 507$ days (ANA 2016).

\section{Selection of sampling sites and sampling periods}

Sampling sites were defined according to a spatially balanced sampling design (Stevens \& Olsen 2004), adapted to large tropical reservoirs (Macedo et al. 2014). Forty equidistant sampling sites were defined starting at a random point in the shore perimeter of Nova Ponte Reservoir. At each sampling site physical habitats were assessed, physical and chemical parameters of water column and sediment granulometry were measured, and benthic macroinvertebrate communities were sampled. Samplings were carried out in April 2010 (regular drought year) and in April 2014 (atypical drought year). In this month, the reservoir is expected to have its maximum volume, offering higher availability of physical habitats to the aquatic biota (Morais et al. 2017). The average volume in 2014 was below the historical average for the 14-year data (Figure 2).

\section{Characterization of land uses}

Land uses were determined by identifying landscape characteristics in the influence areas (buffers) of $500 \mathrm{~m}$ surrounding each sampling site. Buffers were analyzed through satellite images (TM sensor onboard Landsat 5) captured in the same period as the samplings (April 2010 and 2014). Using the Kosmo 2.0 software and images available at Google Earth 6.0, images were interpreted and areas with different land uses were defined (e.g. agriculture, native vegetation, grass fields, pasture, constructions).

\section{Field protocol}

The physical structure of habitats was characterized by applying the Physical Habitat Characterization Protocol (USEPA 2012). At each sampling site, 10 transects were set 15 meters equidistant from each other. In each transect, we assessed continuous sections of coastal zone (wetted

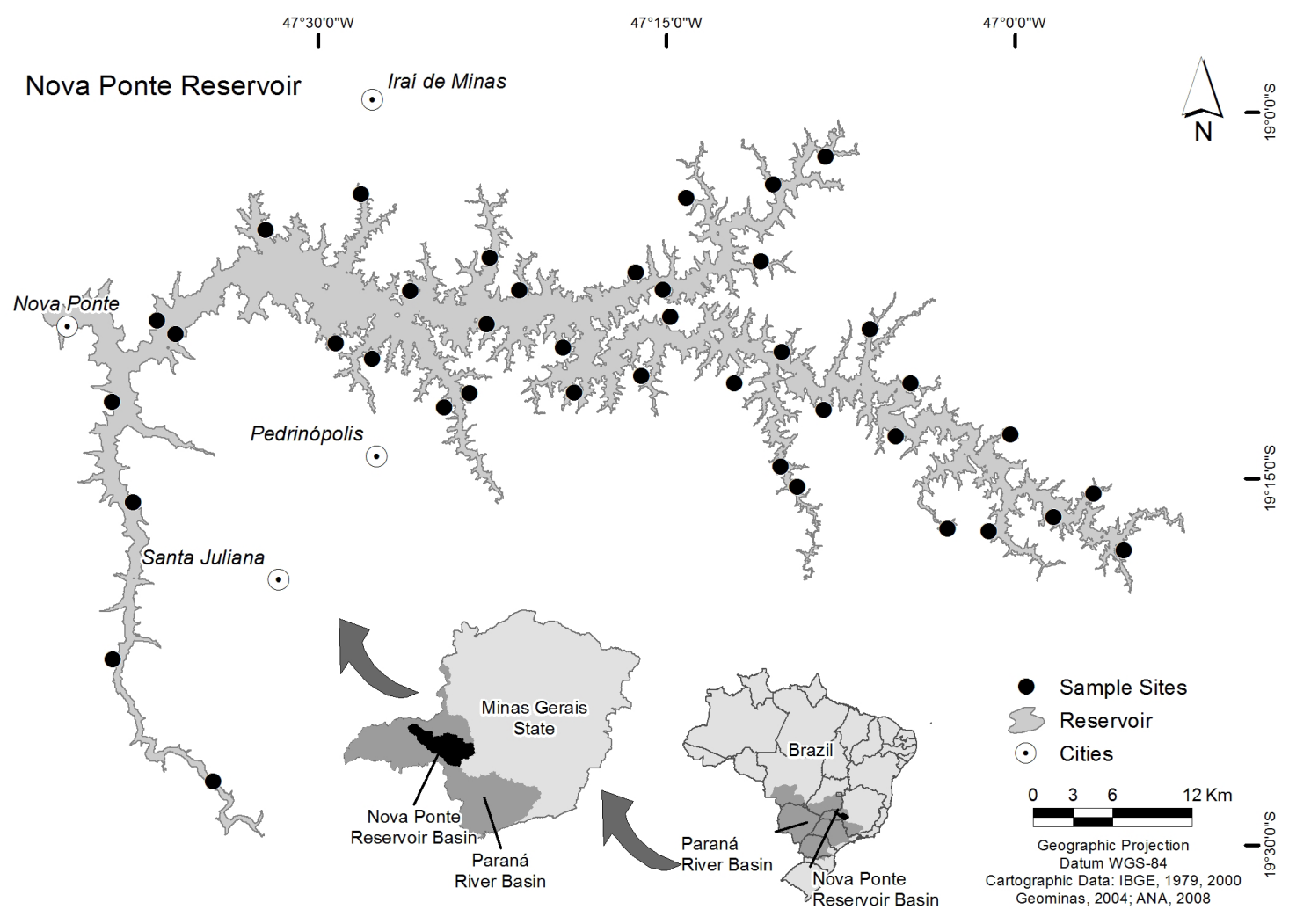

Figure 1. Sampling sites in the Nova Ponte reservoir, Araguari river basin, MG, Brazil. 


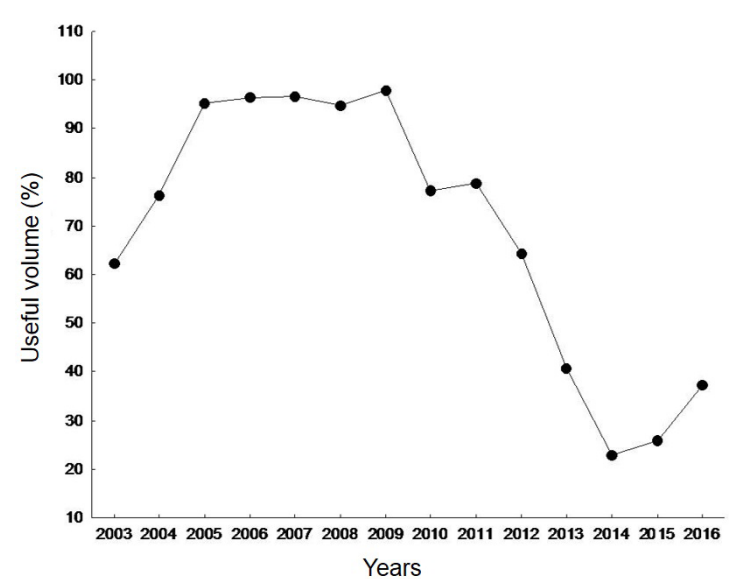

Figure 2. Historical water volume data of Nova Ponte reservoir, Araguari river basin, MG, regarding the month of April from the years of 2003 to 2016.

are next to margins, $15 \times 10 \mathrm{~m})$, flood zone ( $15 \times \mathrm{Y}$ m, where $\mathrm{Y}$ represents the flood zone length, which varies between transects according to the slope of margins at the sampling sites), and riparian zone (above flood zone, 15 x $15 \mathrm{~m}$ ).

\section{Evaluation of limnological parameters and sediment characterization}

Limnological parameters were evaluated at the 40 sampling sites based on measures taken in the subsurface. Water temperature $\left({ }^{\circ} \mathrm{C}\right), \mathrm{pH}$, and electric conductivity $\left(\mu \mathrm{S} \mathrm{cm}^{-1}\right)$ were measured using a multi-analyzer YSI $^{\circledR} 6600$ model. Total depth was measured using a digital meter gauge and water transparency was measured using a Secchi (m) dish. Turbidity (NTU) was measured using a Digimed ${ }^{\circledR}$ turbidimeter. At the laboratory, chlorophyll- $a$ contents $\left(\mu \mathrm{g} \mathrm{L}^{-1}\right)$ were measured according to the methodology by Golterman et al. (1978) and dissolved oxygen contents (mg L) were measured using the Winkler method (1888). Total alkalinity $\left(\mathrm{mEq} \mathrm{L}^{-1} \mathrm{CO}_{2}\right)$ was calculated according to Carmouze (1994). Organic matter contents in the sediment were determined using the gravimetric method, in which aliquots $(0.3 \pm 0.1 \mathrm{~g})$ were calcinated in a muffle furnace at $550^{\circ} \mathrm{C}$ for four hours and then weighed (Esteves et al. 1995). Granulometric composition was analyzed using the sieving method, according to Suguio (1973), modified by Callisto \& Esteves (1996).

\section{Characterization of anthropogenic disturbances}

In order to determine the level of disturbance at each sampling site, three indices were used, according to Ligeiro et al. (2013) and Martins et al. (2015): i) Buffer Disturbance Index (BDI), which reflects the disturbances in the buffer area; ii) Local Disturbance Index (LDI), which reflects disturbances at the local scale; and iii) Integrated Disturbance Index (IDI), which was calculated based on the two previous indices.

BDI was determined based on the percentages of land use inside each buffer $(500 \mathrm{~m})$, and different weights were attributed to each type of land use activity, according to the formula:

$B D I=4 \times(\%$ urban areas $)+2 \times\left(\begin{array}{c}\% \text { agricultural areas }+ \\ \% \text { bare soil area }\end{array}\right)+\%$ pasture areas

The SynRDis_IX index was used as a measure for the LDI. For compound this index we measured several metrics of physical habitat and human alterations along each site (Table 1), and calculations we made according to Kaufmann et al. (2014a, b).
Finally, a disturbance plane was built having the BDI and the LDI as the two axes, and the IDI was calculated as the Euclidian distance between the position of each site relative to the origin of the plane (zero values in both axes) (Ligeiro et al. 2013, Martins et al. 2015). Values farther from the origin represent higher departure from better ecological status, and consequently, higher human modifications. In other words, sampling sites located near the origin of the disturbance plane represent locations minimally changed by human activities, and can be considered as reference areas according to the Maximum Ecological Potential concept (Molozzi et al. 2013a).

\section{Sampling of benthic macroinvertebrates}

Samplings of macroinvertebrate communities were performed at each sampling site using an Eckman-Birge drag (area $\left.0.022 \mathrm{~m}^{2}\right)$. Samples were stored in plastic bags, fixated with $4 \%$ formaldehyde and transported to the Benthic Ecology Laboratory of the Federal University of Minas Gerais. At the laboratory, samples were rinsed individually through two sieves with mesh sizes 1.0 and $0.5 \mathrm{~mm}$. After that, animals were sorted and identified using a stereoscope microscope with 40x magnification. Identification was performed at the family level with the help of specific taxonomic keys (Pérez 1988, Merritt \& Cummins 1996, Carvalho \& Calil 2000, Epler 2001, Fernández \& Domínguez 2001, Costa \& Simonka 2006, Mugnai et al. 2010). Oligochaeta, Hirudinea and Hydracarina were not identified at family. Individuals of the family Chironomidae (Diptera, Insecta) were identified at the genus level, using the taxonomic key by Trivinho-Strixino (2011). Exotic species were identified using specific taxonomic keys (Melo 2003, Pereira et al. 2012, Santos et al. 2012).

\section{Biological metrics calculation}

Some biological metrics were calculated according to Silveira (2004) and Ferreira et al. (2011), namely: i) richness, ii) \% richness, iii) abundance, and iv) \% abundance, for the following data: (a) benthic taxa, (b) Ephemeroptera, Plecoptera and Trichoptera (EPT) (Leptohyphidae, Leptophlebiidae, Polymitarcyidae and Hydropsychidae) as sensitive taxa, (c) tolerant taxa (Staphylinidae, Chaoboridae, Ceratopogonidae, Naucoridae, Gomphidae, Libellulidae and Corixidae), (d) resistant taxa (Oligochaeta), (e) exotic species (Corbicula fluminea Müller 1974, Melanoides tuberculatus Müller 1974, and Macrobrachium amazonicus Heller 1862), (f) genera of Chironomidae.

\section{Data analysis}

\subsection{Assessing spatial correlation among macroinvertebrate communities}

To analyze spatial correlation of macroinvertebrate composition among sampling sites, the Mantel test (Mantel 1967) was performed at each sampling period using the 'vegan' package (Oksanen et al. 2017) of the R program (R Core Team 2017). A Bray-Curtis dissimilarity matrix was built using macroinvertebrate abundance data (transformed in $\log _{10}(x+1)$ ) and a spatial distance matrix was built applying an Euclidian distance in the geographical (lat/long) coordinates (UTM).

We also employed the Moran's I autocorrelation coefficient to evaluate spatial autocorrelation in taxonomic richness and abundance of macroinvertebrates at each sampling period. We used the inverse $(1 / \mathrm{x})$ of the Euclidean distances between pairs of sites as a measurement of distance weight. For these analyses we used the 'ape' package (Paradis et al. 2004), also in $\mathrm{R}$ program ( $\mathrm{R}$ Core Team 2017). 
Effects of a severe drought on macroinvertebrates

Table 1. Metrics used to calculate the Local Disturbance Index (LDI), after Kaufmann et al. (2014a; b).

\begin{tabular}{|c|c|c|c|c|}
\hline Metric & Description & Min & Med & Max \\
\hline Pdraw & Ratio of horizontal drawdown distance divided by the field plot size (15m). & 1.0 & 1.9 & 6.1 \\
\hline rviWoody & Summed coverage of woody vegetation in the canopy, understory and ground cover. & 0.1 & 0.4 & 0.8 \\
\hline rvfcCanBig & Mean proportional areal cover of large diameter trees averaged over the 10 plots. & 0.0 & 0.3 & 0.8 \\
\hline rvfcGrdBare & Mean proportional areal cover of bare ground (soil) averaged over the 10 plots. & 0.0 & 0.1 & 0.6 \\
\hline hifpAnyCirca & Proportion of plots with at least one type of human activity. & 0.0 & 0.2 & 1.0 \\
\hline hiiAg & Proportion of plots with agricultural activities. & 0.0 & 0.1 & 1.9 \\
\hline hiiNonAg & Proportion of plots with non-agricultural activities. & 0.0 & 0.2 & 3.2 \\
\hline hiiAll & Sum of the proportions of plots with agricultural and non-agricultural activities. & 0.0 & 0.3 & 5.1 \\
\hline hiiAllCirca & Proportion between agricultural and non-agricultural activities. & 0.0 & 0.1 & 1.0 \\
\hline
\end{tabular}

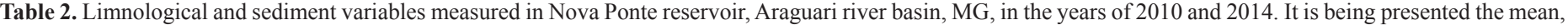
the standard deviation and the results of the paired t-tests (d.f. $=39, * p \leq 0,05)$.

\begin{tabular}{|c|c|c|c|c|}
\hline Variables & 2010 & 2014 & $t$ & $\mathbf{p}$ \\
\hline \% Cobbles (64 - $250 \mathrm{~mm})$ & $0.26 \pm 0.38$ & $0.00 \pm 0.00$ & 4.294 & $<0.001$ \\
\hline$\%$ Gravel $(2-63 \mathrm{~mm})$ & $0.19 \pm 0.24$ & $0.07 \pm 0.12$ & 2.707 & 0.01 \\
\hline$\%$ Fine sand $(0.1-0.249 \mathrm{~mm})$ & $0.33 \pm 0.15$ & $0.42 \pm 0.15$ & -2.466 & 0.01 \\
\hline$\%$ Very Fine Sand $(0.125-0.062 \mathrm{~mm})$ & $0.54 \pm 0.24$ & $0.71 \pm 0.18$ & -3.702 & $<0.001$ \\
\hline $\operatorname{Secchi}(\mathrm{m})$ & $3.13 \pm 1.45$ & $1.47 \pm 1.10$ & 7.994 & $<0.001$ \\
\hline $\mathrm{pH}$ & $7.56 \pm 0.19$ & $7.94 \pm 0.52$ & -3.683 & $<0.001$ \\
\hline Conductivity $\left(\mu \mathrm{S} \mathrm{cm}^{-1}\right)$ & $22.80 \pm 4.21$ & $2.77 \pm 1.47$ & 36.919 & $<0.001$ \\
\hline Turbidity (UNT) & $2.53 \pm 1.47$ & $33.27 \pm 49.24$ & -3.947 & $<0.001$ \\
\hline Chlorophyll $a\left(\mu \mathrm{g} \mathrm{L}^{-1}\right)$ & $0.86 \pm 0.43$ & $1.37 \pm 1.28$ & -2.233 & 0.031 \\
\hline Total alkalinity $\left(\mathrm{mEq} \mathrm{L}-1 \mathrm{CO}_{2}\right)$ & $155.35 \pm 33.16$ & $234.58 \pm 83.74$ & -6.437 & $<0.001$ \\
\hline
\end{tabular}

\subsection{Comparisons of land uses and limnological variables} between years

Paired t-tests were used to analyze the differences of land uses in site buffers and limnological variables between the two sampling years. The percentage data first went through an arcsine square root transformation. BDI, LDI, and IDI values were also compared between sampling years in the same manner. These analyses were performed in the Statistica 6.0 program (Statsoft 2011).

\subsection{Influence of anthropogenic disturbances on the benthic macroinvertebrate community}

Paired t-tests were used to check differences in taxonomic richness and abundance of individuals between sampling years. In order to assess the effects of anthropogenic influences on macroinvertebrate communities at different spatial scales, multiple linear regressions were performed between biological metrics and disturbance indices (BDI, LDI). These analyses were performed separately for each sampling year using the Statistica 6.0 program (Statsoft 2011)

\section{Results}

Types of land use in areas surrounding the sampling sites in Nova Ponte Reservoir showed no striking changes between sampling years. In 2010 , they were represented by grass fields (34.1\%), native vegetation (33.6\%), agriculture $(21.7 \%)$, pasture $(9.4 \%)$, bare soil $(0.9 \%)$, and constructions $(0.3 \%)$. This scenario was generally similar in 2014; fields $(34.0 \%)$ (no change), native vegetation (33.6\%) (no change), agriculture $(22.2 \%)(\mathrm{t}=-1.000, \mathrm{df}=39, \mathrm{p}=0.323)$, pasture $(9.0 \%)$ $(\mathrm{t}=1.000, \mathrm{df}=39 ; \mathrm{p}=0.323)$, bare soil $(0.9 \%)$ (no change), and constructions $(0.3 \%)$ (no change).

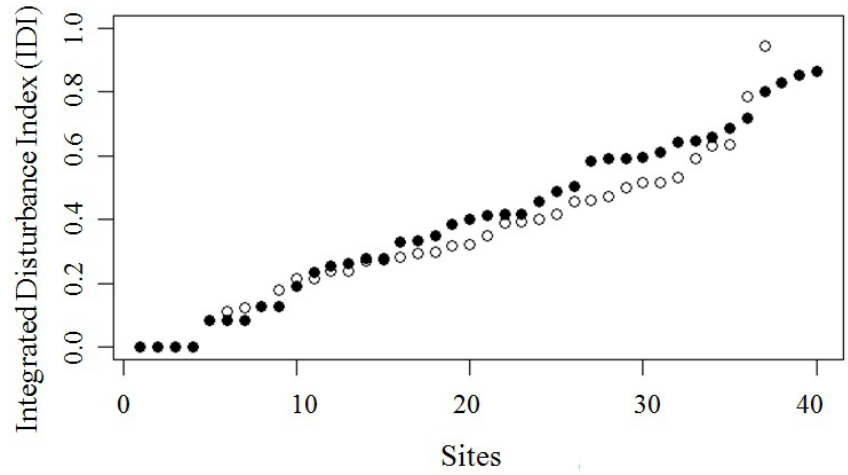

Figure 3. Ordered values of the Integrated Disturbance Index (IDI) of the sites in the years of $2010(\bullet)$ and $2014(\circ)$

Regarding limnological parameters, a quite different scenario was observed between the regular climatological year (2010) and the atypical drought year (2014) (Table 2). In 2010 we observed a higher water conductivity, while in 2014 almost all limnological parameters presented higher values, including $\mathrm{pH}$, turbidity, Chlorophyll-a and total alkalinity. The analysis of granulometric composition in the shore sediment indicated larger particle sizes in 2010 (pebbles and gravels) compared to those obtained in 2014, when we observed a higher proportion of fine and very fine sand.

Disturbance indices results were similar between study years $(\mathrm{LDI}, \mathrm{t}=0.182, \mathrm{df}=39, \mathrm{p}=0.856$; BDI, $\mathrm{t}=-1.000, \mathrm{df}=39, \mathrm{p}=0.323$; IDI, $\mathrm{t}=0.033, \mathrm{df}=39, \mathrm{p}=0.973$ ) (Figure 3 ). This emphasizes that the atypical drought year did not influence anthropogenic stress intensity along the reservoir shoreline. 
Table 3. List of taxa found in Nova Ponte reservoir, Araguari river basin, MG, in the years of 2010 and 2014.

\begin{tabular}{|c|c|c|}
\hline \multirow{2}{*}{ Taxa } & \multicolumn{2}{|c|}{ Abundance } \\
\hline & 2010 & 2014 \\
\hline \multicolumn{3}{|l|}{ Clitellata } \\
\hline Oligochaeta & 470 & 92 \\
\hline Hirudinea & 1 & 0 \\
\hline \multicolumn{3}{|l|}{ Mesogastropoda } \\
\hline Melanoides tuberculatus & 14 & 0 \\
\hline \multicolumn{3}{|l|}{ Veneroida } \\
\hline Corbicula fluminea & 12 & 13 \\
\hline \multicolumn{3}{|l|}{ Decapoda } \\
\hline Macrobrachium amazonicum & 1 & 0 \\
\hline \multicolumn{3}{|l|}{ Trombidiformes } \\
\hline Hydracarina & 4 & 0 \\
\hline \multicolumn{3}{|l|}{ Diptera } \\
\hline Chironomidae & 515 & 390 \\
\hline Chaoboridae & 47 & 439 \\
\hline Ceratopogonidae & 7 & 2 \\
\hline \multicolumn{3}{|l|}{ Ephemeroptera } \\
\hline Leptohyphidae & 16 & 2 \\
\hline Caenidae & 9 & 0 \\
\hline Baetidae & 3 & 0 \\
\hline Leptophlebiidae & 0 & 5 \\
\hline Polymitarcyidae & 0 & 1 \\
\hline \multicolumn{3}{|l|}{ Coleoptera } \\
\hline Elmidae & 1 & 0 \\
\hline Staphylinidae & 0 & 2 \\
\hline \multicolumn{3}{|l|}{ Odonata } \\
\hline Gomphidae & 5 & 6 \\
\hline Libellulidae & 5 & 1 \\
\hline \multicolumn{3}{|l|}{ Lepidoptera } \\
\hline Pyralidae & 1 & 0 \\
\hline \multicolumn{3}{|l|}{ Trichoptera } \\
\hline Leptoceridae & 2 & 0 \\
\hline Polycentropodidae & 3 & 0 \\
\hline Hydropsychidae & 0 & 1 \\
\hline \multicolumn{3}{|l|}{ Hemiptera } \\
\hline Naucoridae & 0 & 1 \\
\hline Corixidae & 0 & 1 \\
\hline
\end{tabular}

A total of 1,116 individuals were identified in 2010, distributed in 18 taxa. The most abundant groups were Chironomidae (46\%) and Oligochaeta (42\%). The 456 Chironomidae were identified in 21 genera, with predominance of Tanytarsus (van der Wulp 1874), which had 45\% of the sampled individuals, and Polypedilum (Kieffer 1912), with 15\%. No significant correlation was observed between the distance between sites and the similarity of their species composition $(\mathrm{R}=0.057, \mathrm{p}=0.22)$. Taxonomic richess and abundance of macroinvertebrates were weakly, but significantly, spatially autocorrelated during this year (Morans' $\mathrm{I}=0.05, \mathrm{p}=0.03$ in both cases).

In 2014, 956 individuals were collected and identified in 14 taxa (46\% Chaoboridae and $41 \%$ Chironomidae) (Table 3). A total of 334 collected individuals of Chironomidae were identified in 22 genera, with predominance of Polypedilum (Kieffer 1912) and Tanypus (Meigen 1803) (each with $22 \%$ of the total) (Table 4 ). Again, no relationship was observed between spatial distances between sites and the similarity of their
Table 4. List of genera of Chironomidae found in Nova Ponte reservoir, Araguari river basin, MG, in the years of 2010 and 2014.

\begin{tabular}{|c|c|c|}
\hline \multirow{2}{*}{ Genera } & \multicolumn{2}{|c|}{ Abundance } \\
\hline & 2010 & 2014 \\
\hline \multicolumn{3}{|l|}{ Tanypodinae } \\
\hline Ablabesmyia Johannsen, 1905 & 15 & 11 \\
\hline Clinotanypus Kieffer, 1913 & 0 & 2 \\
\hline Coelotanypus Kieffer, 1913 & 16 & 11 \\
\hline Djalmabatista Fittkau, 1968 & 2 & 1 \\
\hline Labrundinia Fittkau, 1962 & 2 & 0 \\
\hline Tanypus Meigen, 1803 & 0 & 73 \\
\hline \multicolumn{3}{|l|}{ Orthocladiinae } \\
\hline Cricotopus van der Vulp, 1874 & 36 & 0 \\
\hline Metriocnemus van der Wulp, 1874 & 0 & 1 \\
\hline \multicolumn{3}{|l|}{ Chironominae } \\
\hline Aedokritus Roback, 1958 & 13 & 10 \\
\hline Asheum Sublette, 1964 & 5 & 7 \\
\hline Axarus Roback, 1980 & 2 & 0 \\
\hline Caladomyia Säwedal, 1981 & 5 & 0 \\
\hline Chironomus Meigen, 1803 & 25 & 26 \\
\hline Cladopelma Kieffer, 1921 & 14 & 21 \\
\hline Cryptochironomus Kieffer, 1918 & 2 & 2 \\
\hline Dicrotendipes Kieffer, 1913 & 0 & 3 \\
\hline Fissimentum Cranston \& Nolte, 1996 & 29 & 5 \\
\hline Goeldichironomus Fittkau, 1965 & 5 & 37 \\
\hline Nilothauma Kieffer, 1920 & 4 & 1 \\
\hline Paralauterborniella Lenz, 1941 & 1 & 7 \\
\hline Pelomus Reiss, 1990 & 2 & 9 \\
\hline Polypedilum Kieffer, 1912 & 70 & 73 \\
\hline Saetheria Jackson, 1977 & 1 & 7 \\
\hline Stempellinella Brundin, 1947 & 0 & 1 \\
\hline Stenochironomus Kieffer, 1919 & 3 & 1 \\
\hline Tanytarsus van der Wulp, 1874 & 204 & 25 \\
\hline
\end{tabular}

communities $(\mathrm{R}=-0.007, \mathrm{p}=0.51)$. Taxonomic richess and abundance of macroinvertebrates were not spatially autocorrelated during this year (respectively, Morans' $\mathrm{I}=0.03, \mathrm{p}=0.22$ and Morans' $\mathrm{I}=0.03, \mathrm{p}=0.09$ ).

The richness of macroinvertebrates was significantly lower in the drier year $(\mathrm{t}=2.882$, d.f. $=39, \mathrm{p}=0.006)$, with $2.9 \pm 1.7$ (average \pm standard deviation) taxa sampled in 2010 and $2.1 \pm 0.9$ taxa sampled in 2014 . Macroinvertebrates did not show significant differences in abundance $(\mathrm{t}=0.427$, d.f. $=39, \mathrm{p}=0.671)$, with $27.9 \pm 39.1$ individuals collected in 2010 and $23.9 \pm 41.7$ individuals collected in 2014. On the other hand, there was no change in richness $(t=-0.813$, d.f. $=39, \mathrm{p}=0.420)$ and abundance $(\mathrm{t}=0.727$, d.f. $=39, \mathrm{p}=0.471)$ of genera of Chironomidae between years. Three exotic species were recorded in 2010: Corbicula fluminea (Müller 1974), Melanoides tuberculatus (Müller 1974), and Macrobrachium amazonicus (Heller 1862), whereas only C. fluminea was recorded in 2014.

No biological metric was related with BDI in neither of the two years (Table 5). In 2010, three biological metrics (exotic species abundance, percentage of individuals of exotic species, and percentage of exotic species richness) were significantly related to the LDI; whereas in 2014 only the metric exotic species abundance was significantly related to the LDI (Table 5). 
Table 5. Multiple regression between the biological metrics and the disturbance indexes (IDB and IDL) in Nova Ponte reservoir, Araguari river basin, MG, in the years of 2010 and 2014. Only the response variables which rendered significant models $(* p \leq 0,05)$ were presented.

\begin{tabular}{|c|c|c|c|c|c|c|c|c|c|c|c|c|}
\hline \multirow{3}{*}{ Biological Metrics } & \multicolumn{6}{|c|}{2010} & \multicolumn{6}{|c|}{2014} \\
\hline & \multicolumn{2}{|c|}{ IDB } & \multicolumn{2}{|c|}{ IDL } & \multirow{2}{*}{$\mathbf{F}(2,37)$} & \multirow{2}{*}{$\mathbf{p}$} & \multicolumn{2}{|c|}{ IDB } & \multicolumn{2}{|c|}{ IDL } & \multirow{2}{*}{$\mathbf{F}(2,37)$} & \multirow{2}{*}{$\mathbf{p}$} \\
\hline & p- level & B & p-level & B & & & p-level & B & p-level & B & & \\
\hline Abundance of non-native species & 0.614 & 0.035 & $0.005^{*}$ & 0.186 & 4.554 & 0.017 & 0.559 & 0.029 & $0.007^{*}$ & 0.106 & 4.215 & 0.022 \\
\hline Percent of non-native individuals & 0.870 & 0.674 & $0.011^{*}$ & 10.014 & 3.610 & 0.036 & 0.876 & 0.571 & 0.066 & 5.204 & 1.793 & 0.180 \\
\hline Percent non-native species richness & 0.465 & -0.025 & $0.017 *$ & -0.076 & 3.423 & 0.043 & 0.979 & 0.083 & 0.127 & 3.818 & 1.214 & 0.308 \\
\hline
\end{tabular}

\section{Discussion}

The 2014 drought in southeastern Brazil was considered atypical for the region (IGAM 2014, ANA 2016). A water shortage crisis followed this episode in several parts of the country because of the low rainfall and also due to the poor management of water resources and the widespread environmental degradation related to anthropogenic activities (Dobrovolski \& Rattis 2015). The total rain recorded over the previous two periods (2012/2013 and 2013/2014) were lower than the climatological normal, and these years were classified respectively as 'slightly dry' to 'very dry' (IGAM 2014, ANA 2016). Consequently, changes in the macroinvertebrate community, in the limnological parameters, and in the physical habitats of the Nova Ponte Reservoir were observed in 2014.

Macroinvertebrate taxonomic richness was lower in the atypical drought year (2014), but there was no change in the richness and abundance of genera of Chironomidae between years. Higher climatic unpredictability and the occurrence of extreme events have been seriously affecting aquatic biodiversity (Lake 2003). Hydrological disturbances might lead to changes in the characteristics of the environment, as observed in our study, since limnological parameters and habitat characteristics were strikingly different between the regular climatological year (2010) and the atypical drought year (2014). Water shortage led to decreased water level in the reservoir, and consequently, to increased $\mathrm{pH}$, suspended solid contents, and chlorophyll-a, all of which are relevant factors to the structuring of benthic communities (Navarro et al. 2009). We also observed that decreased water volume led to changes in the granulometric composition of sediments, with predominance of finer particles in the drier year. This might be explained by shore retreat in the horizontal profile of the reservoir due to water level depletion. Therefore, the area which was a limnetic region in 2010 became a littoral region in 2014 due to water depletion, and this might have contributed to the lower macroinvertebrate diversity observed in this atypical drought year. Granulometric composition has been considered to be the factor with the highest influence on the distribution of benthic macroinvertebrates at a local scale in tropical reservoirs (Molozzi et al. 2013b). Hence, the more diversified the sediment, the higher the availability of shelters and protection for these organisms (Molozzi et al. 2011, Zerlin \& Henry 2014).

Oligochaeta and larvae of Chironomidae and Chaoboridae were present and abundant in both sampling periods. In 2014, these organisms were the dominant taxa. This might be attributed to the high resistance of these groups to changes caused by water level depletion in the reservoir (Dollar et al. 2013, Morais et al. 2017). In addition, these organisms have high reproduction rates, and might adapt to sudden changes in water quality (Ledger et al. 2013). Chaoboridae are represented by cosmopolitan and voracious organisms which predate other invertebrates, especially zooplankton. They might be found in the sediment during the day and in the water column at night, and are common in reservoirs (Zerlin \& Henry 2014). Many Chironomidae larvae inhabit harsh habitats, such as fine sediments, hot waters, and low oxygen contents (Ledger et al. 2012). The genus Tanypus was one of the most abundant in 2014. These larvae have preference for shallow places, and are adapted to fluctuations in environmental conditions. They are also known as organic pollution-tolerant organisms (Silva et al. 2009). On the other hand, the genera Cricotopus, Fissimentum and Tanytarsus presented a sharp decrease of abundance in the drought year, revealing the bioindicator potential of these genera (Morais et al. 2010). The decrease in the abundance of Oligochaeta in 2014 may indicate the preference of this group for littoral zones in reservoirs (Azêvedo et al. 2015), which were exposed during the water stress.

Our results showed that disturbance index values (Integrated Disturbance Index-IDI, Buffer Disturbance Index-BDI, and Local Disturbance Index-LDI) underwent minimum changes in Nova Ponte Reservoir when both study years were compared. Thus, the decrease observed in taxonomic richness was, in fact, due to the water stress event and not to increased human disturbance around the reservoir. Overall, Local Disturbance Index (LDI) better explained the variation in community structure than the Buffer Disturbance Index (BDI). This contrasts with the pattern usually observed in lotic ecosystems, such as streams, where disturbances acting in the drainage basin typically have higher influence on community structure (Martel et al. 2007, Kail et al. 2012, Ligeiro et al. 2013). Reservoirs are essentially artificial environments created for several different purposes, including electric power generation and water for human consumption (Tundisi \& Matsumura-Tundisi 2008). Thus, this large-scale artificial condition is probably minimizing the importance of landscape elements operating in the area around sampling sites (buffers), and local-scale disturbance is more likely to have influence over the aquatic biota (Molozzi et al. 2013a). Therefore, our findings indicate that the management of artificial ecosystems must be based on premises other than those used for natural ecosystems. We encourage further studies to test the generality of this statement. Additionally, the effects of anthropogenic disturbance indices (LDI, BDI) on biological variables were more evident in 2010, which was within the climatological normal for that region. This suggests that the large-scale water stress which occurred in 2014 overrode the importance of both land uses and local habitat disturbances for the macroinvertebrate communities. In other words, large-scale climatic events negatively affect the ecological integrity of reservoirs, regardless of the conditions in their aquatic habitats and their surrounding areas. This corroborates findings of studies by international agencies, which emphasize the need for stopping and reversing severe global climate changes (IPCC 2016, Boersma et al. 2016). If that is not done, habitat management and conservation measures conducted at more limited scales will be of little use.

Exotic species were also negatively influenced by the water stress event. In 2014, these species presented quite decreased richness and abundance. Corbicula fluminea was the only exotic species found in 2014, although in lower numbers. This species has a remarkable capacity of re-colonizing and recovering its abundance after the occurrence of disturbances (Sousa et al. 2008). Some studies have demonstrated that increased turbidity might increase mollusk mortality (Avelar et al. 2014, Neves et al. 2014). Sediment type might also influence the mortality of these organisms, since very fine fractions require higher energy expenditure to keep the individuals in the sediment, and they might also clog the pallial cavity (Vianna \& Avelar 2010). In addition, changes in several factors during drought, such as increased temperature, $\mathrm{pH}$, and turbidity, might increase the mortality of benthic organisms, whether exotic or not (Sousa et al. 2008). The presence of exotic species can lead to a pauperization of 
macroinvertebrate communities (Linares et al., 2017). In this way, one can expect an amelioration of ecosystem integrity with the removal of those species. However, in this study the water stress impacted greatly both native and exotic species, so that any positive consequence resultant from this removal could not be detected. Therefore, if the patterns observed in this case study are confirmed, it is possible that water stress events might work as a barrier for the advance of exotic species distribution in reservoirs. On the other hand, metacommunity dynamics might also buffer local extinction events, keeping these species in the regional pool (Leibold et al. 2004, Brown et al. 2011).

\section{Conclusion}

Although our temporal sampling effort was too short (normal versus atypical drought, one year each), our study provides important information about atypical drought conditions, creating unique opportunities to understand the ecological effect of climate changes in tropical reservoirs. The water level depletion caused in Nova Ponte Reservoir by an atypical drought event affected both limnological parameters of water and sediment size in the shore, thus influencing benthic macroinvertebrate communities. Nevertheless, the level of anthropogenic disturbances did not change between years, indicating that the drought per se did not influence the intensity of human intervention observed in local habitats and in the areas surrounding sampling sites (buffers). Our hypothesis that an extreme drought event is detrimental to macroinvertebrate communities was generally corroborated. However, our prediction that exotic species would benefit from the water stress event was not, as we observed a reduction in the richness and abundance of these organisms during that period. Although some genera of Chironomidae presented a decreased abundance due to the water stress, most genera tolerated well the drought conditions, confirming the high environmental plasticity of this group. Our results indicate that damaging effects caused by a large-scale water stress event might override the effects of habitat integrity in reservoirs and their surrounding landscapes, which has important implications for the management of these artificial environments in a setting of global climate changes.

\section{Acknowledgments}

We thank the Peixe-Vivo Program of Companhia Energética de Minas Gerais, Pesquisa e Desenvolvimento/Agência Nacional de Energia Elétrica/Companhia Energética de Minas Gerais - P\&D ANEEL/CEMIG (GT-487), Coordenação de Aperfeiçoamento de Pessoal de Nível Superior (PROCAD-CAPES), Conselho Nacional de Desenvolvimento Científico e Tecnológico (CNPq); Carlos Bernardo Mascarenhas Alves for his logistic support; and colleagues from the Benthic Ecology Laboratory of the Federal University of Minas Gerais, for helping with field samplings. MC was awarded research productivity CNPq (no. 303380/2015-2), research project CNPq (no. 446155/2014-4), and Minas Gerais research grant FAPEMIG PPM-IX - 00525-15. The State University of Paraíba Benthic Ecology Laboratory (UEPB) supported the senior author.

\section{Author Contributions}

Raphael Ligeiro: Contribution to data analysis and interpretation; Contribution to manuscript preparation; Contribution to critical revision, adding intelectual content.

José Etham de L. Barbosa: Contribution to critical revision, adding intelectual content.

Joseline Molozzi: Contribution to data analysis and interpretation; Contribution to critical revision, adding intelectual content.
Marcos Callisto: Substantial contribution in the concept and design of the study; Contribution to data collection; Contribution to manuscript preparation; Contribution to critical revision, adding intelectual content.

\section{Conflicts of interest}

The authors declare that they have no conflict of interest related to the publication of this manuscript.

\section{References}

ANA. http://www2.ana.gov.br/reservatorios (the last access in 19/11/2016).

ÁRVA, D., SPECZIÁR, A., ERÖS, T. \& TÓTH, M. 2015. Effects of habitat types and within lake environmental gradients on the diversity of chironomid assemblages. Limnologica. doi.org/10.1016/j.limno.2015.05.004.

AVELAR, W.E.P., NEVES, F.F. \& LAVRADOR, M.A.S. 2014. Modelling the risk of mortality of Corbicula fluminea (Müller, 1774) (Bivalvia: Corbiculidae) exposed to different turbidity conditions. Braz. J. Biol. 74(2): 509-514.

AZEVÊDO, D.J.S., BARBOSA, J.E.L. GOMES, W.I.A., PORTO, D.E., MARQUES, J.C. \& MOLOZZI, J. 2015. Diversity measures in macroinvertebrate and zooplankton communities related to the trophic status of subtropical reservoirs: Contradictory or complementary responses? Ecol. Indic. 50: 135-149.

AZEVÊDO, E.L., BARBOSA, J.E.L., VIDIGAL, T.H.A., MARQUES, J.C., CALLISTO, M. \& MOLOZZI, J. 2016. Potential ecological distribution of alien mollusk Corbicula largillierti and its relationship with human disturbance in a semi-arid reservoir. Biota Neotrop. 16(1): e0109. http://dx.doi.org/10.1590/16760611-BN-2015-0109.

BOERSMA, K.S., NICKERSON, A., FRANCIS, C.D. \& SIEPIELSKI, A.M. 2016 Climate extremes are associated with invertebrate taxonomic and functional composition in mountain lakes. Ecol. Evol. 6(22): 8094-8106.

BOND, N.R., LAKE, P.S. \& ARTHINGTON, A.H. 2008. The impacts of drought on freshwater ecosystems: an Australian perspective. Hydrobiologia, 600: 3-16.

BORISOV, R.R., CHERTOPRUD, E.S. \& KOVACHEVA, N.P. 2016. Water quality assessment in reservoirs: comparative analysis of bioindication systems based on macrobenthos characteristics. Water Resour. (43)5: 544-554.

BRANDIMARTE, A.L., ANAYA, M. \& SHIMIZU, G.Y. 2016. Impact of damming on the Chironomidae of the upper zone of a tropical run-of-the-river reservoir. Braz. J. Biol. (76)2: 402-411.

BROWN, B.L., SWAN, C.M., AUERBACH, D.A., CAMPBELL GRANT, E.H., HITT, N.P., MALONEY, K.O. \& PATRICK, C. 2011. Metacommunity theory as a multispecies, multiscale framework for studying the influence of river network structure on riverine communities and ecosystems. J. N. Am. Benthol. Soc. 30(1): 310-327.

CASTRO, D.M.P., DOLÉDEC, S. \& CALLISTO, M. 2017. Landscape variables influence taxonomic and trait composition of insect assemblages in neotropical savanna streams. Freshwater Biol. 1-15. doi: 10.1111/fwb.12961

CALLISTO, M. \& ESTEVES, F. 1996. Composição granulométrica do sedimento de um lago amazônico impactado por rejeito de bauxita e um lago natural. Acta Limnol. Bras. 8: 115-126.

CARPENTER, S.R., STANLEY, E.H. \& ZANDEN, M.J.V. 2011. State of the world's freshwater ecosystems: physical, chemical, and biological changes. Annu. Rev. Env. Resour. 36: 75-99.

CARMOUZE, J.P. 1994. O metabolismo dos ecossistemas aquáticos: fundamentos teóricos, métodos de estudo e análises químicas. São Paulo: Ed. Edgard Blücher, FAPESP, p. 255.

CARVALHO, A.L. \& CALIL, E.R. 2000. Chaves de identificação para famílias de Odonata (Insecta) ocorrentes no Brasil, adultos e larvas. Pap. Avulsos Zool 41(15): 223-241

CEMIG. Http://www.cemig.com.br/pt_br/a_cemig/Nossa_Historia/Paginas/ Usinas_Hidreletricas (the last access in 18/03/2015).

CORBI, J.J. \& TRIVINHO-STRIXINO, S. 2016. Chironomid species are sensitive to sugarcane cultivation. Hydrobiologia. doi:10.1007/s10750-016-2908-2.

COSTA, C.S. \& SIMONKA, C.S. 2006. Insetos Imaturos Metamorfose e Identificação. RibeirãoPreto. Ed. Helos, p. 249. 
DOBROVOLSKI, R. \& RATTIS, L. 2015. Water collapse in Brasil: the danger of relying on what you neglect. Nat.Conservação. 13: 80-90.

DOLLAR, E., EDWARDS, F., STRATFORD, C., MAY, L., BIGGS, J., LAIZE, C., ACREMAN, M., BLAKE, J., CARVALHO, L., ELLIOTT, A., GUNN, I., HINSLEY, S., MOUNTFORD, O., NUNN, M., PRESTON, C., SAYER, E., SCHONROGGE, K., SPEARS, B., SPURGEON, D., WINFIELD, I. \& WOOD, P. 2013. Monitoring and Assessment of Environmental Impacts of Droughts. Literature Synthesis, Report:SC120024/R1. Environment Agency, p. 24-29. https://www.environment-agency.gov.uk.

DURÃES, R., POMPEU, P.S. \& GODINHO, A.L. 2001. Alimentação de quatro espécies de Leporinus (Characiformes, Anostomidae) durante a formação de um reservatório no sudeste do Brasil. Iheringia Ser. Zool. 90: 183-191.

EPLER, J.H. 2001. Identification manual for the larval Chironomidae (Diptera) of North and South Carolina. Department of Environmental and Natural Resources. Division of Water quality. Raleigh and St. Johns River Water Management District, Palatka, p. 526.

ESTEVES, F.A., SUZUKI, M.S., CALlistO, M. \& PERES-NETO, P.R. 1995. Teores de matéria orgânica, carbono orgânico, nitrogênio, fósforo e feopigmentos no sedimento de alguns ecossistemas lacustres do litoral do Estado do Espírito Santo. Oecologia Brasiliensis. 1: 407-417.

FERREIRA, W.R., HEPP, L.U., LIGEIRO, R., MACEDO, D.R., HUGHES, R.M., KAUFMANN, P.R., \& CALLISTO, M. 2017. Partitioning taxonomic diversity of aquatic insect assemblages and funcional feeding groups in neotropical savanna headwater streams. Ecol. Indic. 72: 365-373.

FERREIRA, W.R., PAIVA, L.T. \& CALLISTO, M. 2011. Development of a benthic multimetric index for biomonitoring of a neotropical watershed. Braz. J. Biol. 71(1): $15-25$

FERNÁNDEZ, H.R. \& DOMÍNGUES, E. 2001. Guia para la determinación de los artrópodos bentônicos Sudamericanos. Universidad Nacional de Tucumán. Facultad de Ciencias Naturales e Instituto M. Lillo, Tucumán, p. 282.

GAETA, J.W., SASS, G.G. \& CARPENTER, S.R. 2014. Drought-driven lake level decline: effects on coarse woody habitat and fishes. Can. J. Fish. Aquat. Sci. 71: 315-325.

GAMA, M., CRESPO, D., DOLBETH, M. \& ANASTÁCIO, P.M. 2017. Ensemble forecasting of Corbicula fluminea worldwide distribution: projections of the impact of climate change. Aquatic Conserv: Mar Freshw Ecosyst. 27: 675-684.

GETIRANA, A. 2015. Extreme water deficit in Brazil detected from space. J. Hydrometeor. doi:10.1175/JHM-D-15-0096.1, in press.

GOLTERMAN, H.L., CLYMO, R.S. \& OHNSTAD, M.A.M. 1978. Methods for physical and chemical analisys of fresh waters. Oxford: Blackwell Scientific, p. 214.

HOFMANN, H., LORKE, A. \& PEETERS, F. 2008. Temporal scales of water-level fluctuations in lakes and their ecological implications. Hydrobiologia. 613: 85-96.

IGAM. 2014. Estudos de avaliação da precipitação em bacias do estado: Acordo de resultados 2014. http://www.igam.mg.gov.br/gestao-das-aguas (the last access 10/03/2015).

ILYASHUK, B.P. \& ILYASHUK, E.A. 2007. Chironomid record of Late Quaternary climatic and environmental changes from two sites in Central Asia (Tuva Republic, Russia) local, regional or global causes? Quaternary Sci. Rev. 26: 705-731.

IPCC. 2016. Intergovernmental Panel on Climate Change. https://www.ipcc.ch/ report/ar5/wg1(the last access 24/08/2017).

KAIL, J., ARLEB, J. \& JÄHNIG, S.C. 2012. Limiting factors and thresholds for macroinvertebrate assemblages in European rivers: empirical evidence from three datasets on water quality, catchment urbanization, and river restoration. Ecol. Indic. 18: 63-72.

KAUFMANN, P.R., HUGHES, R.M., SICKLE, J.V., WHITTIER, T.R., SEELIGER, C.W. \& PAULSEN, S.G. 2014a. Lake shore andlittoral physical habitat structure: A field survey method and its precision. Lake Reserv. Manage. 30(2): 157-176.

KAUFMANN, P.R., HUGHES, R.M., WHITTIER, T.R., BRYCE, S.A. \& PAULSEN, S.G. 2014b. Relevance of lake physical habitat indices to fish and riparian birds. Lake Reserv. Manage. 30(2): 177-19.

LAKE, P.S. 2000. Disturbance, patchiness, and diversity in streams. J. N. AM. Benthol. Soc. 19(4): 573-592.
LAKE, P.S. 2003. Ecological effects of perturbation by drought in flowing waters. Freshwater Biol. 48: 1161-1172.

LEDGER, M.E., HARRIS, R.M.L., ARMITAGE, P.D. \& MILNER, A.M. 2012. Climate change impacts on community resilience: evidence from a drought disturbance experiment. Adv. Ecol. Res. 46: 211-258.

LEDGER, M.E., BROWN, L.E., EDWARDS, F.K., HUDSON, L.N., MILNER, A.M. \& WOODWARD, G. 2013. Extreme climatic events alter aquatic food webs: asynthesis of evidence from a mesocosm drought experiment. Adv. Ecol. Res. 48: 343-395.

LEIBOLD, M.A., HOLYOAK, M., MOUQUET, N., AMARASEKARE, P., CHASE, J.M., HOOPES, M.F., \& LOREAU, M. 2004. The metacommunity concept: a framework for multi-scale community ecology. Ecol. Lett. 7: 601-613.

LIGEIRO, R., HUGHES, R.M., KAUFMANN, P.R., MACEDO, D.R., FIRMIANO, K.R., FERREIRA, W., OLIVEIRA, D., MELO, A.S. \& CALLISTO, M. 2013. Defining quantitative stream disturbance gradients and the additive role of habitat variation to explain macroinvertebrate taxa richness. Ecol. Indic. 25: 45-57.

LINARES, M.S., CALLISTO, M. \& MARQUES, J.C. 2017. Invasive bivalves increase benthic communities complexity in neotropical reservoirs. Ecol. Indic. 75: 279-285.

MACEDO, D.R., POMPEU, P.S., MORAIS, L., CASTRO, M.A., ALVES, C.B.M., FRANÇA, J.S., SANCHES, B., UCHÔA, J. \& CALLISTO, M. 2014. Sampling site selection, land use and cover, field reconnaissance, and sampling. In: Callisto, M., Hughes, R.M., Lopes, J.M., Castro, M.A. (eds.), Ecologicalconditions in hydropowerbasins. Belo Horizonte: Companhia Energética de Minas Gerais, (Série Peixe Vivo, 3), p. 61-83.

MACEDO, D.R., HUGHES, R.M., FERREIRA, W.R., FIRMIANO, K.R., SILVA, D.R.O., LIGEIRO, R., KAUFMANN, P.R. \& CALLISTO, M. 2016. Development of benthic macroinvertebrate multimetric index (MMI) for Neotropical Savanna headwater streams. Ecol. Indic. 64: 132-141.

MACKAY, F., CYRUS, D. \& RUSSELL, K.L. 2010. Macrobenthic invertebrate responses to prolonged drought in South Africa's largest estuarine lake complex. Estuarine, Coastal and Shelf Science. 86(4): 553-567.

MAGBANUA, F. S., MENDOZA, N. Y. B., UY, C. J. C., MATTHAEI, C. D. \& ONG, P. S. 2015. Water physicochemistry and benthic macroinvertebrate communities in a tropical reservoir: the role of water level fluctuations and water depth. Limnologica. http://dx.doi.org/10.1016/j.limno.2015.10.002.

MANTEL, N.A. 1967. The detection of disease clustering and a generalized regression approach. Cancer Res. 27: 209-220.

MARENGO, J.A. 2009. Mudanças climáticas, condições meteorológicas extremas e eventos climáticos no Brasil. http://www.fbds.org.br/cop15/ FBDS_MudancasClimaticas.pdf.

MARTEL, N., RODRIGUEZ, M.A. \& BÉRUBÉ, P. 2007. Multi-scale analysis of responses of stream macrobenthos to forestry activities and environmental context. Freshwater Biol. 52: 85-97.

MARTINS, I., SANCHES, B., KAUFMANN, P.R., HUGHES, R.M., SANTOS, G.B., MOLOZZI, J. \& CALLISTO, M. 2015. Ecological assessment of a southeastern Brazil reservoir. Biota Neotrop. 15(1): e20140061. http://dx.doi. org/10.1590/1676-06032015006114.

MCDOWELL, W.G., MCDOWELL, W.H. \& BYERS, J.E. 2017. Mass mortality of a dominant invasive species in response to an extreme climate event: Implications for ecosystem function. Limnol. Oceanogr. 62: 177-188.

MELO, G.A.S. 2003. Manual de identificação dos crustacea decapoda de água doce do Brasil. Editora Loyola, São Paulo, p. 430.

MERRITT, R.W. \& CUMMINS, K.W. 1996. An introduction to the aquatic insects of North America, 3rd ed. Kendall/Hunt Publishing Company, Dubuque, Iowa, v. 3, p. 862 .

MOLOZZI, J., FRANÇA, J.S., ARAUJO, T.L.A., VIANA, T.H., HUGHES, R.M. \& CALLISTO, M. 2011. Diversidade de habitats físicos e sua relação com macroinvertebrados bentônicos em reservatórios urbanos em Minas Gerais. Iheringia Ser. Zool. 101(3): 191-199.

MOLOZZI, J., FEIO, M.J., SALAS, F., MARQUES, J.C. \& CALLISTO, M. 2013 a. Maximum ecological potential of tropical reservoirs and benthic invertebrate communities. Environ. Monit. Assess. 185(8): 6591-6606. 
MOLOZZI, J., HEPP, L.U., \& CALLISTO, M. 2013b. The additive partitioning of macroinvertebrate diversity in tropical reservoirs. Mar. Freshwater Res. 64(7): 609-617. doi: 10.1071/MF12354.

MORAIS, L., DE OLIVEIRA SANCHES, B., SANTOS, G.B., KAUFMANN, P.R., HUGHES, R.M., MOLOZZI, J. \& CALLISTO, M. 2017. Assessment of disturbance at three spatial scales in two large tropical reservoirs. J. Limnol. doi: http://dx.doi.org/10.4081/jlimnol.2016.1547.

MORAIS, S.S., MOLOZZI, J., VIANA, A.L., VIANA, T.H., \& CALLISTO, M. 2010. Diversity of larvae of littoral Chironomidae (Diptera: Insecta) and their role as bioindicadors in urban reservoirs of different trophic levels. Braz. J. Biol. 70(4): 995-1004

MUGNAI, R., NESSIMIAN, J.L. \& BAPTISTA, D.F. 2010. Manual de identificação de macroinvertebrados aquáticos do Estado do Rio de Janeiro. Editora Technical Books, Rio de Janeiro, p. 176.

NAVARRO, E., CAPUTO, L., MARCÉ. R., CAROL, J., BENEJAM, L., GARCÍABERTHOU, E. \& ARMENGOL, J. 2009. Ecological classification of a set of Mediterranean reservoirs applying the EU Water Framework Directive: A reasonable compromise between science and management. Lake and Reserv. Manage. 25: 364-376.

NEVES, F.F., LAVRADOR, M.A.S., COSTA, A.S. \& AVELAR, W.E.P. 2014. The effect of exposure to suspended sediment in mortality of Corbicula fluminea (Müller, 1774) (Bivalvia: Corbiculidae). Am. J. Life Sci. 2(3): 150-154.

OKSANEN, J., BLANCHET, F.G., FRIENDLY, M., KINDT, R., LEGENDRE, P., MCGLINN, D., MINCHIN, P.R., O'HARA, R.B., SIMPSON, G.L., SOLYMOS, P., STEVENS, M.H.H., SZOECS, E. \& WAGNER, H. 2017. Vegan: Community Ecology Package. R package version 2.4-3. https://CRAN.R-project.org/ packege $=$ vegan

ONS, Operador Nacional do Sistema Elétrico. http://www.ons.org.br/tabela reservatorios/conteudo.asp (the last access 17/03/2015).

PARADIS, E., CLAUDE, J. \& STRIMMER, K. 2004. APE: analyses of phylogenetics and evolution in R language. Bioinformatics 20: 289-290.

PEREIRA, D., MANSUR, M.C.D. \& PIMPÃO, D.M. 2012. Identificação e diferenciação dos bivalves límnicos invasores dos demais bivalves nativos do Brasil. In: Mansur, M.C.D., Santos, C.P., Pereira, D., Paz, I.C.P., Zurita, M.L.L., Rodriguez, M.T.R., Nehrke, M.V., Bergonci, P.E.A. (Org.), Moluscos límnicos invasores no Brasil: biologia, prevenção e controle. Redes Editora, Porto Alegre, p. 75-94.

PÉREZ, G.P. 1988. Guía para el studio de los macroinvertebrados acuáticos del departamento de Antioquia. Editorial Presencia Ltda. Bogotá, p. 217

RAHEL, F.J. \& OLDEN, J.D. 2008. Assessing the effects of climate change on aquatic invasive species. Conserv. Biol. 22(3): 521-533.

RESH, V. H., BÊCHE, L.A., LAWRENCE, J.E., MAJOR, R.D., MCELRAVY, E.P., O'DOWD, D., RUDNICK, D. \& CARLSON, S.M. 2013. Long-term population and community patterns of benthic macroinvertebrates and fishes in Northerm California Mediterranean-climate streams. Hydrobiological. 719: 93-118.

ROCHA, O., ESPÍNDOLA, E.L., RIETZLER, A.C., FENERICH-VERANI, N \& VERANI, J.R. 2011. Animal invaders in São Paulo state reservoirs. Oecol. Aust. 15(3): 631-642. doi:10.4257/oeco.2011.1503.14.

ROMM, J. 2011. Desertification: The next dust bowl. Nature. 478: 450-451. doi:10.1038/478450a.

R Core Team 2017. R: A language and environment for statistical computing. R Foundation for Statistical Computing, Vienna, Austria, URL https: //www.Rproject.org/.

SANTOS, S.B., THIENGO, S.C., FERNANDEZ, M.A., MIYAHIRA, I.C., GONÇALVES, I.C.B., XIMENES, R.D.F. \& PEREIRA, D. 2012. Espécies de moluscos límnicos invasores no Brasil. In: MANSUR, M.C.D., SANTOS, C.P., PEREIRA, D., PAZ, I.C.P., ZURITA, M.L.L., RODRIGUEZ, M.T.R.,
NEHRKE, M.V., BERGONCI, P.E.A. (Org.), Moluscos límnicos invasores no Brasil: biologia, prevenção e controle. Redes Editora, Porto Alegre, p. 25-49.

SAULINO, H.H., LEITE-ROSSI L.A. \& TRIVINHO-STRIXINO, S. 2017. The effect of small reservoirs on chironomid diversity and trait composition in Savanna streams: evidence for Serial Discontinuity Concept. Hydrobiologia. 793: 109-119.

SILVA, E.C. \& BARROS, F. 2011. Macrofauna bentônica introduzida no Brasil: lista de espécies marinhas e dulcícolas e distribuição atual. Oecol. Aust. 15(2): 326-344.

SILVA, F.L. 2009. Functional trophic categorization of macroinvertebratecomumunities of two reservoirs in the midwestern region of São Paulo state. Brazil. Acta Sci Biol. Sci. 31(1): 73-78.

SILVEIRA, M.P. 2004. Aplicação do biomonitoramento para avaliação da qualidade da água em rios. Embrapa Meio Ambiente, Jaguariúna, p. 68.

SOUSA, R., ANTUNES, C. \& GUILHERMINO, L. 2008. Ecology of the invasive Asian clam Corbicula fluminea (Müller, 1774) in aquatic ecosystems: an overview. Ann. Limnol. Int. J. Lim. 44(2): 85-94.

STATSOFT. 2011. Statistica (data analysis software system). http://www.statsoft. com (the last access in 22/09/2014)

STEVENS, D.L. \& OLSEN, A.R. 2004. Spatially balanced sampling of natural resources. J. Am. Stat. Assoc. 99: 262-278.

STRAYER, D.L. 2010. Alien species in fresh waters: ecological effects, interactions with other stressors, and prospects for the future. Freshwater Biol. 55: 152-174.

SUGUIO, K. 1973. Introdução à sedimentologia. Ed. Edgard Blucher, EDUSP, São Paulo, p. 317.

SUTELA, T., AROVIITA, J. \& KETOC, A. 2013. Assessing ecological status of regulated lakes with littoral macrophyte, macroinvertebrate and fish assemblages. Ecol. Indic. 24: 185-192.

TANER, M.Ü., CARLETON, J.N. \& WELLMAN, M. 2011. Integrated model projections of climate change impacts on a North American lake. Ecol. Model. 222: 3380-3393.

TANG, Q., BAO, Y., HE, X., FU, B., COLLINS, A.L. \& ZHANG, X. 2016. Flow regulation manipulates contemporary seasonal sedimentary dynamics in the reservoir fluctuation zone of the Three Gorges Reservoir, China. Sci. Total Environ. 548(549): 410-420.

TRIVINHO-STRIXINO, S. 2011. Larvas de Chironomidae: Guia de identificação. São Carlos. Depto. Hidrobiologia/Lab. Entomologia Aquática/UFSCar, p. 371

TUNDISI, J.G. \& MATSUMURA-TUNDISI, T. 2008. Limnologia. São Paulo: Oficina de Textos, Capitulo 12, p. 313.

USEPA. 2012. Nacional Lakes Assessment. Field Operations Manual. EPA. 841-B11-003. U.S. Environmental Protection Agency, Washington, DC

VIANNA, M.P. \& AVELAR, E.P.A. 2010. Ocorrência da espécie invasora Corbicula fluminea (Bivalvia, Corbiculidae) no rio Sapucaí (São Paulo, Brasil), Biotemas. 23(3): 59-66.

WILLIAMSON, C.E., SAROS, J.E. \& SCHINDLER, D.W. 2009. Sentinels of Change. Science. 323: 887-888.

WINKLER, L.W. 1888. Die Bertimmung des imwassergelösten Sauer-stoffs. Ber. Dtsch. Chem. Ges. 21: 2843-2854.

ZERLIN, R.A. \& HENRY, R. 2014. Does water level affect benthic macroinvertebrates of a marginal lake in a tropical river-reservoir transition zone? Braz. J. Biol. 74(2): 408-419.

Received: $28 / 03 / 2017$

Revised: 30/01/2018

Accepted: 06/02/2018

Published online: 08/03/2018 